\title{
In Patients with Recurrent Pilonidal Sinus, Should the First Approach be Crystallised Phenol or Limberg Flap?
} Nüks Pilonidal Sinüs Hastalarında İlk Yaklaşım Kristalize Fenol mü,
Limberg Flep mi Olmalı?

\author{
(1) Mustafa Şentürk1, (1) Yusuf Yavuz² \\ ${ }^{1}$ Necmettin Erbakan University Meram Medicine Faculty, Department of General Surgery, Konya, Turkey \\ 2Şanlıurfa Training and Research Hospital, Clinic of General Surgery, Şanlıurfa, Turkey
}

\section{\|I\|\|\|II| ABSTRACT}

Aim: In our study, we aimed to compare the efficacy of Limberg flap and crystallised phenol treatments applied to patients with recurrent pilonidal sinus.

Method: Patients with recurrent pilonidal sinus disease who were treated with the surgical excision Limberg flap technique and crystallised phenol method in our hospital General Surgery Clinic between 2017 and 2019 were evaluated retrospectively. The patients were assessed according to age, gender, hospital stay, smoking, infection, return-to-work period and recurrence rates.

Results: A total of 25 patients who underwent Limberg flap treatment due to recurrent disease and 32 patients who were treated with the phenol method were identified retrospectively. Patients with missing data were excluded, and 40 patients were included in the study. In all, $72.5 \%$ of the patients were male. The mean age of the Limberg group was $25.25 \pm 6.12$, and that of the crystallised phenol group was $24.60 \pm 6.11$. While the mean hospital stay was $2.05 \pm 0.75$ days in the Limberg group, all patients were discharged on the same day in the crystallised phenol group (p<0.001). The return-to-work period in the Limberg group was significantly higher $(\mathrm{p}<0.001)$. The cosmetic appearance was significantly better in the crystallised phenol group $(\mathrm{p}=0.02)$.

Conclusion: The less invasive method of phenol treatment may be preferred as the first treatment method in recurrent patients since it is more advantageous than the post-excision flap procedures in terms of the length of hospital stay and cosmetics.

Keywords: Recurrent pilonidal sinus, crystallised phenol, Limberg flap

\section{|IIIIIII|| ÖZ}

Amaç: Çalışmamızda nüks pilonidal sinüslü hastalara uygulanan Limberg flep ve kristalize fenol tedavilerinin etkinliğini karşılaştırmayı amaçladık. Yöntem: Hastanemiz genel cerrahi kliniğinde, 2017-2019 tarihleri arasında cerrahi eksizyon Limberg flep tekniği ve kristalize fenol yöntemi ile tedavi edilen nüks pilonidal sinüs hastalığı tanısı alan hastalar retrospektif olarak değerlendirildi. Olgular yaş, cinsiyet, hastanede kalış süresi, sigara, enfeksiyon, işe dönüş süresi ve nüks oranlarına göre değerlendirildi.

Bulgular: Nüks hastalık nedeniyle işlem yapılan hasta dosyaları arasından Limberg flep uygulanan 25 hasta ve fenol uygulaması yapılan 32 hasta geriye dönük tespit edildi. Eksik verileri olan hastalar dışlandı ve 40 hasta çalışmaya dahil edildi. Hastaların \% 72,5 ’ erkekti. Limberg grubunun yaş

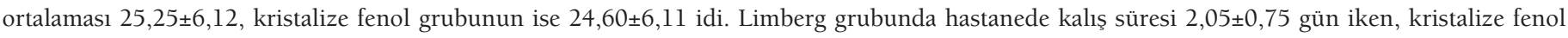
grubunda tüm olgular aynı gün taburcu edildi $(\mathrm{p}<0,001)$. Kozmetik görünüm kristalize fenol grubunda anlamlı yüksekti ( $\mathrm{p}=0,02)$.

Sonuç: Daha az invaziv yöntem olan fenol tedavisinin, eksizyon sonrası flep prosedürlerine göre hastanede yatış süresi ve kozmetik acısından daha avantajlı olması nüks hastalarda ilk tedavi yöntemi olarak tercih edilebilir.

Anahtar Kelimeler: Tekrarlayan pilonidal sinüs, kristalize fenol, Limberg flep 


\section{Introduction}

Pilonidal sinus is a common disease of the sacrococcygeal region that is usually seen among young men. The incidence is reported as 26 per 100,000 population. ${ }^{1}$ Theories are presented to explain the aetiology, but the widely accepted opinion is that the disease is acquired. ${ }^{2}$ There are many opinions in the literature on the treatment of pilonidal sinus disease. Treatment options range from minimally invasive surgical procedures to complex flap techniques. Although some studies report that flap techniques are associated with lower recurrence rates and higher patient satisfaction compared with other surgical procedures, there are several studies suggesting that flap techniques are over-surgery. ${ }^{3}$ The ideal treatment of pilonidal sinus disease should include simple and easy-to-apply surgery, a low recurrence rate, a short duration of hospitalisation, a rapid return to daily activity and minimal scar tissue formation. ${ }^{4,5}$

Today, phenol treatment, which includes these properties, is defined as a conservative method and has emerged as the initial treatment in some clinics, is another treatment method. Phenol is a monosubstituted aromatic hydrocarbon with acidic properties. It has antiseptic, anaesthetic and potent sclerosing properties. While it is in a white, crystallised solid form at room temperature, it can take on the liquid form at higher temperatures. ${ }^{4,6}$ Both the liquid and the crystallised forms are used in treatment. There is no consensus on the treatment of pilonidal sinus disease. In our study, we aimed to compare the results of patients treated with crystalline phenol and Limberg flap in patients with recurrent pilonidal sinus.

\section{Materials and Methods}

Patients diagnosed with recurrent pilonidal sinus disease who were treated with the surgical excision Limberg flap technique and crystallised phenol method in our hospital General Surgery Clinic between 2017 and 2019 were retrospectively evaluated. Patients signed an informed consent form for the surgical procedure and subsequent treatment, and the necessary permission was obtained to use their data in our analyses. Patients who previously had a history of operation due to pilonidal sinus and who developed a pilonidal sinus were included in the study. Two groups were formed. Twenty-five patients who underwent Limberg flap treatment due to the recurrent disease and 32 patients who were treated with the phenol method, were identified retrospectively. Among the files of patients who had been treated for pilonidal sinus, 40 patients were randomly selected from both groups and included in the study. The first group included 20 patients treated with the
Limberg flap method, while the second group included 20 patients treated with crystallised phenol. Phenol treatment was applied three times at most. Those who did not respond to treatment after the third application were directed to surgery. The patients' age, gender, length of hospital stay, follow-up period, smoking, return-to-work period, infection and recurrence rates were evaluated. Evaluation of application complications, infection, recurrence and cosmetic appearance was recorded in the outpatient clinic follow-up. Healing was defined as the absence of any signs of infection at the wound site and epithelialisation of the skin. Patients who missed their follow-up appointment were called by phone and rescheduled.

Crystallised Phenol Method: Phenol was applied to all patients under local anaesthesia and in the outpatient clinic. The pit was expanded with the help of the clamp, and hair and debris were removed. The cyst epithelium was curetted. After the pit edge was protected with nitrofurazone pomade, the sinus was filled with crystallised phenol with the help of a clamp from the expanded part. The wound was dressed and the procedure terminated (Figure 1).

Limberg Flap Method: All patients underwent spinal anaesthesia. A rhomboid excision including post-sacral fascia was performed to excise all of the sinus tracts. A fasciocutaneous flap was prepared from the right or the left side of the gluteal region including gluteal fascia. The flap was sutured to presacral fascia and subcutaneous skin with $1 / 0$ polyglactin sutures. The skin was closed in interrupted 3/0 monofilament polypropylene sutures. A hemovac drain was used in all patients (Figure 2).

\section{Statistical Analysis}

Statistical analysis was performed using the SPSS (10.0, SPSS Inc., Chicago, Illinois, USA, Statistical Package for Social Sciences) computer program. Continuous variables

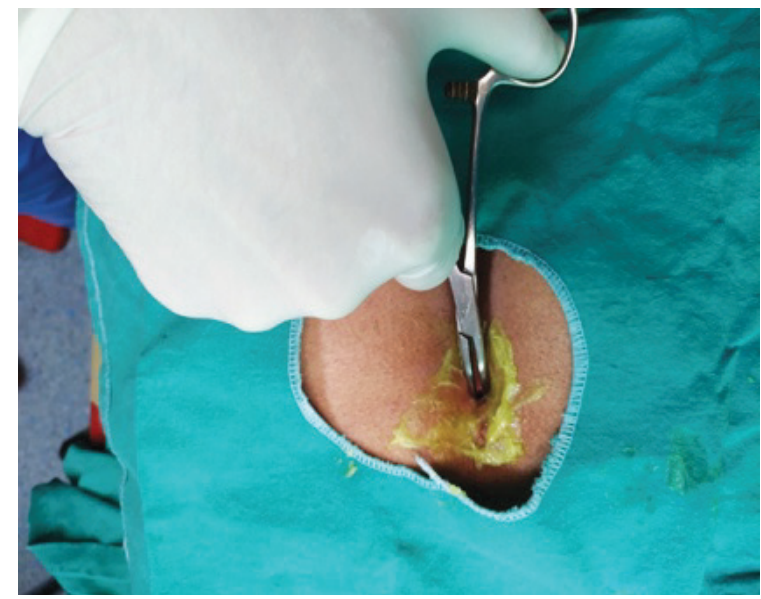

Figure 1. Phenol treatment after sinus curettage 
were expressed as mean \pm standard deviation. Categorical variables were expressed as percentage (\%). The parametric variables that did not show a normal distribution between the groups were compared with the Mann-Whitney U test. Chi-square and Fisher's chi-square exact tests were used to compare categorical variables. $\mathrm{P}<0.05$ was considered significant for all statistical analyses.

\section{Results}

In all, $72.5 \%$ of the patients were male ( $\mathrm{n}=15$ males in the Limberg group, $\mathrm{n}=14$ males in the crystallised phenol group). The mean age of the Limberg group was $25.25 \pm 6.12$ years, while the mean age of the crystallised phenol group was $24.60 \pm 6.11$. There was no significant difference between the two groups in terms of age and gender. While the hospital stay was $2.05 \pm 0.75$ days in the Limberg group, all patients were discharged on the same day in the crystallised phenol group ( $\mathrm{p}<0.001$ ). There was no significant difference between groups in terms of postoperative infection $(\mathrm{p}=0.69)$. Sixteen patients $(40 \%)$ were smokers. No statistically significant difference was found between smoking and recurrence. The mean return-to-work period was $21.75 \pm 9.63$ days in the first group and $2.35 \pm 0.74$ days in the second group. The returnto-work period in the Limberg group was significantly higher $(\mathrm{p}<0.001)$. The follow-up period was $9.70 \pm 2.31$ months in the Limberg group and $12.45 \pm 2.32$ in the crystallised phenol group. During this follow-up period, there was one $(5 \%)$ recurrence in the Limberg group and two (10\%) recurrences in the crystallised phenol group. The groups did not show a statistically significant difference in terms of recurrence $(p=0.50)$. The cosmetic appearance was significantly better in the crystallised phenol group ( $\mathrm{p}=0.02)$ (Table 1). In their first surgery, eight patients underwent Limberg flap and 32 patients had primary repair.

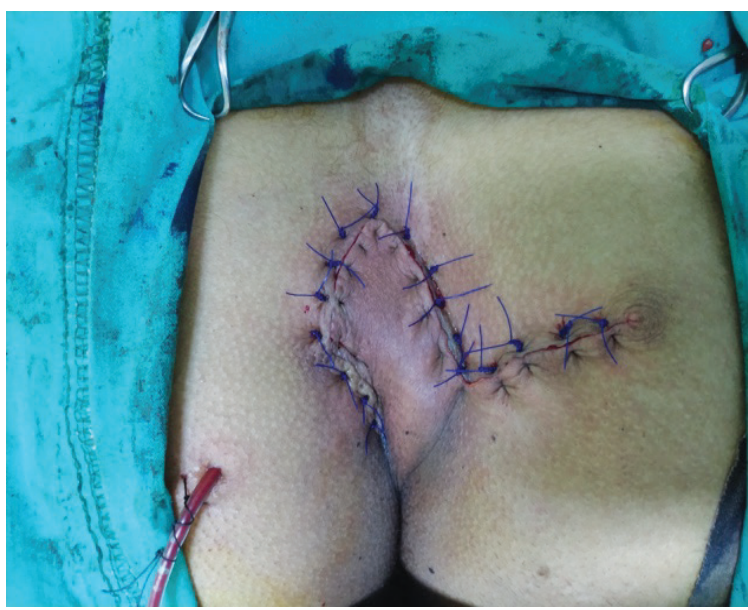

Figure 2. After modified Limberg flap reconstruction

\section{Discussion}

There are various surgical and conservative methods for the treatment of pilonidal sinus. The choice of a treatment is determined by the cost, type of anaesthesia, and return to daily life period. ${ }^{7}$ The lay-open method was initially performed after excision. Subsequently, closure techniques were applied for reasons such as a long recovery time, post-excision defects and a long return-to-work period. Conservative methods, which have less tissue loss, reduce cosmetic problems and shorten the time to return to daily life ${ }^{8}$, have been used in the recent times. Phenol treatment is one of them. Phenol therapy has several advantages. It is a minimally invasive and outpatient procedure, leaving minimal postoperative scarring and requiring no hospitalisation. Therefore, it has been suggested that phenol treatment improves patients' quality of life. ${ }^{9}$ The only disadvantage is that it has higher recurrence rates than flap surgery. However, the data on phenol treatment were obtained from a single application. The success rate can be increased with subsequent phenol applications..$^{10}$ Kayaalp et al. ${ }^{11}$ reported $70 \%$ success after a 14 -month follow-up in a study that used liquid phenol as a single application. Dogru et al. ${ }^{12}$ reported a $95.1 \%$ success rate in a series of 41 cases of crystallised phenol with recurrent cures. Aygen et al. ${ }^{13}$ applied crystallised phenol to 36 patients with recurrent pilonidal sinus, who had previously undergone primary repair and flap procedures and reported a $91 \%$ success rate following a 54-month follow-up. In our study, following a follow-up period of approximately 11 months, our success rate was 95\% in the Limberg-treated group and 90\% in the crystallised phenol group, showing consistency with the literature.

Table 1. Clinical and demographic variables

\begin{tabular}{|c|c|c|c|}
\hline & $\begin{array}{l}\text { Limberg flep } \\
\text { (Grup 1) }\end{array}$ & $\begin{array}{l}\text { Crystallized } \\
\text { phenol (Grup 2) }\end{array}$ & $\mathrm{p}$ value \\
\hline Gender M/F & $15-5(\% 75 \mathrm{M})$ & $14-6(\% 70 \mathrm{M})$ & $>0.05$ \\
\hline Age (years) & $25.25 \pm 6.12$ & $24.60 \pm 6.11$ & $>0.05$ \\
\hline $\begin{array}{l}\text { Cosmetic } \\
\text { complaints }\end{array}$ & $5(\% 25)$ & 0 & 0.24 \\
\hline Recurrence & $2(\% 10)$ & $1(\% 5)$ & 0.50 \\
\hline İnfection & $2(\% 10)$ & $2(\% 10)$ & 0.69 \\
\hline $\begin{array}{l}\text { Time of } \\
\text { commencement } \\
\text { work }\end{array}$ & $21.75 \pm 9.63$ & $2.35 \pm 0.74$ & $<0.001$ \\
\hline $\begin{array}{l}\text { Length of hospital } \\
\text { stay (days) }\end{array}$ & $2.05 \pm 0.75$ & 0 & $<0.001$ \\
\hline Follow - up time & $9.70 \pm 2.31$ & $12.45 \pm 2.32$ & - \\
\hline Smoke & $9(\% 45)$ & $7(\% 35)$ & - \\
\hline
\end{tabular}


The treatment modality and follow-up period are two factors affecting the recurrence rate in pilonidal sinus disease. Surgical site infection and hematoma have been suggested to increase the recurrence rate in pilonidal sinus disease. ${ }^{13,14}$ In our study, there was no statistically significant difference between recurrence and infection $(\mathrm{p}=0.27)$. The most common complications of phenol are pain, abscess, cellulite, and the formation of false canals caused by high pressure during treatment. ${ }^{15}$ In the literature, there are publications stating that smoking increases the complication rate after pilonidal sinus treatment. ${ }^{16}$ However, there was no statistically significant difference between smoking and infection in our study. Although the rate of infection was lower in patients treated with phenol, the difference between the groups was statistically insignificant.

In the group treated with phenol, there was a significant decrease in the length of hospital stay. ${ }^{17}$ Our data support the findings previously reported in many studies. There are publications in the literature stating that the follow-up period after pilonidal sinus surgery should be 1 year or 3 years. ${ }^{18}$ In our study, the mean follow-up period was 9.70 \pm 2.31 months in the Limberg group and $12.45 \pm 2.32$ months in the crystallised phenol group. In their study that compared crystallised phenol and the Limberg flap technique, Akan et al. ${ }^{19}$ reported an $8 \%$ recurrence rate for the flap group and $12 \%$ for the phenol group. The authors noted that the phenol group had a superior cosmetic appearance. ${ }^{19} \mathrm{~A}$ large scar was observed after the Limberg flap was modified; the scar left after the reconstruction, phenol application, which caused a generally unpleasant aesthetic appearance, was almost unclear. In our study, five patients complained of a poor aesthetic appearance in the first group, while all patients were satisfied in the second group ( $\mathrm{p}=0.02)$. Again, there was one $(5 \%)$ recurrence in the Limberg group and two (10\%) recurrences in the crystallised phenol group. Both cases share similarities with the literature. The returnto-work period was significantly higher in the phenol group $(\mathrm{p}<0.001)$.

The limitations of our study were its retrospective nature, relatively short follow-up period and the low number of cases. However, our results suggest that crystallised phenol may be superior to the Limberg flap. There is a need for more studies on this topic.

Compared to the Limberg flap technique, patients treated with crystallised phenol had fewer wound-healing complications, shorter hospitalisations, shorter return-to-work periods and faster wound healing. Albeit not statistically significant, the number of recurrences was low. An unpleasant scar was observed after the flap procedure, whereas after phenol administration, the scar was remarkable. Considering all these, crystallised phenol may be preferred as a first-line treatment option in patients who have been operated on as a first-line treatment and who have developed recurrence.

\section{Ethics}

Ethics Committee Approval: Obtaining the consent of an ethics committee was not necessary for this retrospective clinical study. However, consent was obtained from the hospital management for processing the data.

Informed Consent: Patients signed an informed consent form for the surgical procedure and subsequent treatment, and the necessary permission was obtained to use their data in our analyses.

Peer-review: Internally and externally peer reviewed.

\section{Authorship Contributions}

Surgical and Medical Practices: M.S.., Y.Y., Concept: M.S.., Design: M.S.., Data Collection or Processing: M.Ş., Y.Y., Analysis or Interpretation: M.Ş., Y.Y., Literature Search: M.S.., Writing: Y.Y.

Conflict of Interest: No conflict of interest was declared by the authors.

Financial Disclosure: The authors declared that this study received no financial support.

\section{References}

1. Sarı R, Akbaba S, Gündoğdu RH, Yazıcıoğlu MÖ. Comparison of VY Flap and Limberg Flap Methods in Pilonidal Sinus Surgery. Turk J Colorectal Dis 2019;29:69-74.

2. Chintapatla S, Safarani N, Kumar S, Haboubi N. Sacrococcygeal pilonidal sinus: historical review, pathological insight and surgical options. Tech Coloproctol 2003; 7:3e8

3. Bayhan Z, Zeren S, Duzgun SA, Ucar BI, Alparslan Yumun HN, Mestan M. Crystallized phenol application and modified Limberg flap procedure in treatment of pilonidal sinus disease: A comparative retrospective study. Asian J Surg 2016;39:172-177.

4. Dag A, Colak T, Turkmenoglu O, Sozutek A, Gundogdu R. Phenol procedure for pilonidal sinus disease and risk factors for treatment failure. Surgery 2012;151:113-117.

5. Tavassoli A, Noorshafiee S, Nazarzadeh R. Comparison of excision with primary repair versus Limberg flap. Int J Surg 2011;9:343-346.

6. Gülpinar K, Pampal A, Ozis SE, Kuzu MA. Non-operative therapy for pilonidal sinus in adolescence: crystallised phenol application, "report of a case". BMJ Case Rep 2013; 2013. pii: bcr2012008382.

7. Ölmez A, Kayaalp C, Aydın C. Treatment of pilonidal disease by combination of pit excision and phenol application. Tech Coloproctol 2013;17:201-206.

8. Ataallah W, Coşkun Ş, Coşkun M, Solmaz A, Yegen C, Gencosmanoglu R. The impact of crystalline phenol application as a minimal invasive treatment modality for pilonidal sinus disease. Turk J Colorectal Dis 2015;25:28-33.

9. Sit M, Aktas G, Yilmaz EE. Comparison of the three surgical flap techniques in pilonidal sinus surgery. Am Surg 2013;79:1263e1268.

10. Girgin M, Kanat BH. The results of a one-time crystallized phenol application for pilonidal sinus disease. Indian J Surg 2014;76:17e20.

11. Kayaalp C, Olmez A, Aydın C, Piskin T, Kahraman L. Investigation of one-time phenol application for pilonidal disease. Med Princ Pract 2010;19:212-215. 
12. Dogru O, Camci C, Aygen E, Girgin M, Topuz O. Pilonidalsinus treated with crystallized phenol: an eight-year experience.Dis Colon Rectum 2004;47:1934-1938.

13. Aygen E, Arslan K, Dogru O, Basbug M, Camci C. Crystallized phenol in nonoperative treatment of previously operated, recurrent pilonidal disease. Dis Colon Rectum 2010;53:932-935.

14. Ardelt M, Dittmar Y, Kocijan R, et al. Microbiology of the infected recurrent sacrococcygeal pilonidal sinus. Int Wound J. 2014.

15. Ergin A, Sipahi M, Talih T. A Different Approach to the Treatment Ofpreviously Operated Recurrent Pilonidal Disease. Bozok Med J 2018;8:113-116
16. Al-Khayat H, Al-Khayat H, Sadeq A, Groof A, Haider HH, Hayati H, et al. Risk Factors for Wound Complication in Pilonidal Sinus Procedures. J Am Coll Surg 2007;205:439-444.

17. Topuz O, Sozen S, Tukenmez M, Topuz S, Vurdem UE. Crystallized phenol treatment of pilonidal disease improves quality of life. Indian J Surg 2014;76:81e84

18. Mahdy T. Surgical treatment of the pilonidal disease: primary closure or flap reconstruction after excision. Dis Colon Rectum 2008;51:1816-1822.

19. Akan K, Ihan D, Duman U, Ozgun Y, Erol F, Polat M. Pilonidal sinus tedavisinde cerrahi Limberg flep yontemi ile kristalize fenol uygulamasinın retrospektif karşılaştırılması. Turk J Surg 2013; 29:162-166. 